\title{
Workplace stress in nursing workers from an emergency hospital: Job Stress Scale analysis ${ }^{1}$
}

\author{
Janete de Souza Urbanetto ${ }^{2}$ \\ Priscila Costa da Silva ${ }^{3}$ \\ Eveline Hoffmeister ${ }^{4}$ \\ Bianca Souza de Negri ${ }^{3}$ \\ Bartira Ercília Pinheiro da Costa ${ }^{5}$ \\ Carlos Eduardo Poli de Figueiredo ${ }^{6}$
}

This study identifies workplace stress according to the Job Stress Scale and associates it with socio-demographic and occupational variables of nursing workers from an emergency hospital. This is a cross-sectional study and data were collected through a questionnaire applied to 388 nursing professionals. Descriptive statistics were applied; univariate and multivariate analyses were performed. The results indicate there is a significant association with being a nursing technician or auxiliary, working in the position for more than 15 years, and having low social support, with 3.84, 2.25 and 4.79 times more chances of being placed in the 'high strain job' quadrant. The study reveals that aspects related to the workplace should be monitored by competent agencies in order to improve the quality of life of nursing workers.

Descriptors: Stress, Physiological; Occupational Health; Surveillance of the Workers Health; Nursing.

\footnotetext{
1 Paper extracted from Doctoral Dissertation "Estresse no trabalho e hipertensão arterial em trabalhadores de enfermagem de um hospital de pronto socorro", presented to Faculdade de Enfermagem Fisioterapia e Nutrição, Pontifícia Universidade Católica do Rio Grande do Sul, Porto Alegre, RS, Brazil.

${ }^{2}$ RN, Ph.D. in Health Sciences, Adjunct Professor, Faculdade de Enfermagem Fisioterapia e Nutrição, Pontifícia Universidade Católica do Rio Grande do Sul, Porto Alegre, RS, Brazil. E-mail: jurbanetto@pucrs.br.

${ }^{3}$ Undergraduate student in Nursing, Faculdade de Enfermagem Fisioterapia e Nutrição, Pontifícia Universidade Católica do Rio Grande do Sul, Porto Alegre, RS, Brazil. E-mail: Priscila - pricosts@yahoo.com.br, Bianca - bianca.denegrisouza@gmail.com.

${ }^{4}$ RN, Master's student in Health Sciences, Faculdade de Enfermagem Fisioterapia e Nutrição, Pontifícia Universidade Católica do Rio Grande do Sul, Porto Alegre, RS, Brazil. E-mail: ive_hoff@yahoo.com.br.

${ }^{5}$ Biologist, Ph.D. in Cellular and Molecular Biology, Adjunct Professor, Instituto de Pesquisas Biomédicas, Pontifícia Universidade Católica do Rio Grande do Sul, Porto Alegre, RS, Brazil. E-mail: bart@pucrs.br.

${ }^{6}$ Physician, Ph.D. in Philosophy, Full Profesor, Faculdade de Medicina, Pontifícia Universidade Católica do Rio Grande do Sul, Porto Alegre, RS, Brasil. E-mail: cepoli@pucrs.br.
}

Corresponding Author:

Janete de Souza Urbanetto

Av. Ipiranga, 6681, Prédio 12

Bairro: Partenon

CEP: 90619-900, Porto Alegre, RS, Brasil

E-mail: jurbanetto@pucrs.br 


\section{Estresse no trabalho da enfermagem em hospital de pronto-socorro: análise usando a Job Stress Scale}

Trata-se de estudo cujo objetivo foi identificar o estresse no trabalho, segundo a Job Stress Scale, e associá-lo aos aspectos sociodemográficos e laborais de trabalhadores de enfermagem de um hospital de pronto-socorro. É estudo tipo transversal, cujos dados foram coletados por meio de questionário, com 388 profissionais de enfermagem. A análise foi realizada pela estatística descritiva, análise univariada e multivariada. Através dos resultados identificaram-se associação significativa com o cargo de técnico/auxiliar de enfermagem, tempo no cargo superior a 15 anos e baixo apoio social, com chances respectivas de 3,84, 2,25 e 4,79 maiores para o quadrante alto desgaste. Demonstra-se, assim, que os aspectos relacionados ao ambiente de trabalho devem ser acompanhadas pelos órgãos competentes no intuito de investir na qualidade de vida no trabalho da enfermagem.

Descritores: Estresse Fisiológico; Saúde do Trabalhador; Vigilância em Saúde do Trabalhador; Enfermagem.

\section{Estrés en el trabajo de enfermería en hospital de emergencia: análisis usando la Job Stress Scale}

Estudio que tuvo el objetivo identificar el estrés en el trabajo, según la Job Stress Scale y asociarlo con aspectos sociodemográficos y laborales de trabajadores de enfermería de un hospital de emergencia. Estudio de tipo transversal, cuyos datos fueron recolectados, por medio de cuestionario, con 388 profesionales de enfermería. El análisis fue realizado con la estadística descriptiva, análisis univariado y multivariado. Los resultados identificaron asociación significativa con el cargo de técnico/auxiliar de enfermería, tiempo en el cargo superior a 15 años y bajo apoyo social, con chances respectivas de 3,$84 ; 2,25$ y 4,79 mayores para el cuadrante alto desgaste. El estudio demostró que los aspectos relacionados al ambiente de trabajo deben ser acompañados por los órganos competentes con la finalidad de invertir recursos en la calidad de vida en el trabajo de la enfermería.

Descriptores: Estrés Fisiológico; Salud Laboral; Vigilancia de la Salud del Trabajador; Enfermería.

\section{Introduction}

Workplace stress has been extensively studied in recent years from different perspectives aiming to identify its importance in the etiology of workers' health disorders ${ }^{(1-7)}$. Among the models used to evaluate occupational stress, as well as its implications on the health of individuals, the Demand-Control Model stands out $^{(8-10)}$. It assumes that occupational stress is a result of imbalance between psychological demands and how much control one has over his/her work, which can harm the health of workers. Hence, the greater the demand and the less control one has over his/her work, the greater the risk an individual will become physically or psychologically ill(9).

Control over work encompasses aspects related to the use of intellectual skills (the extent to which the job involves learning, repetitiveness, creativity, varied tasks, and the development of individual special abilities) and decision-making authority (individual ability to make decisions over one's own job, influence held over a group's work, and managerial policies). Psychological demand refers to psychological requirements faced by workers during the performance of tasks. Social 
support in turn refers to issues related to relationships established with co-workers and bosses ${ }^{(8-10)}$.

The dimensions 'psychological demand' and 'control over job' gave origin to the four quadrants of the Demand-Control Model: 'high strain jobs', 'active jobs', 'passive jobs', and 'low strain jobs'. The quadrants 'low strain jobs' and 'active jobs' are reported by the author as the ones having the lowest association with a risk of becoming sick, while the 'high strain jobs' and 'passive jobs' are those most associated with such a risk $^{(8-10)}$.

Many studies have sought associations between high strain jobs according to the Demand-Control Model and health disorders. Hypertension(3,7), minor psychological disorders ${ }^{(1-2)}$ and musculoskeletal pain ${ }^{(5)}$ are among the main studied disorders; many of these studies have found positive association between such disorders and high strain.

Two studies involving public institutions, both Brazilian $^{(3)}$ and international(11), which used the DemandControl Model, report the possibility that job stability affects the perception of workers; requirements accruing from the work process may be minimized given their perception.

Even though studies addressing health disorders in nursing workers have considerably developed in recent years, the relationship of such disorders with stressing factors in the workplace still requires greater clarification. In this context, identifying the profile of nursing professionals working in emergency hospital services in relation to their perceptions concerning psychological demands and control over their jobs can support the planning and implementation of actions toward a better quality of life and quality of life at work, both on the part of nursing workers and managers of health facilities.

In this context and following the line of investigation of other studies, this study identifies occupational stress through the Job Stress Scale (JSS) and verifies its association with socio-demographic and occupational aspects of emergency service nursing workers.

\section{Method}

This cross-sectional study was conducted at a hospital emergency service in the southern region of Brazil. The studied population was composed of nursing workers (nurses, nursing technicians and auxiliaries) from the nursing service of this facility, totaling 606 workers. The target population was invited to voluntarily participate through posters hung in care areas and in meetings specific to each field.

A total of 185 workers were excluded from the study. These comprised all temporary workers, those working at the facility for less than one year, those on leave (sick leave, maternity leave, personal problems, etc.), or formally occupying a managerial position and also those who worked in fields providing indirect care to patients. Of the 421 workers who met the inclusion criteria, $33(7.8 \%)$ did not agree to participate in the study. Therefore, the sample was composed of 388 (92.2\%) nursing workers, in a non-probabilistic convenience sample.

Data were collected through interviews and questionnaires from February to June, 2010. To evaluate occupational stress, the short version( ${ }^{(9)}$ of the DemandControl Model instrument was used, the Job Stress Scale, which was translated and validated in Brazil(10). This version has 17 questions, five to evaluate psychological demand at work (scores ranging from 5 to 20), six questions to evaluate control over job (scores from 6 to $24)$, and another six questions to evaluate social support (scores ranging from 6 to 24$)^{(8-10)}$.

The demand-control quadrants were defined based on analyses of the dimensions 'psychological demand' and 'control over job'. Each dimension generated a score that resulted from the sum of scores obtained by each of the questions and was then classified as "low" or "high" after normal distribution was confirmed through averaging. Low demand (score $\leq 15$ ) or high demand (score $\geq 16$ ) was defined with an average score of 14.64 $( \pm 2.4)$. For dimension control, low (score $\leq 17$ ) or high control (score $\geq 18$ ) was defined with an average score of $16.88( \pm 2.3)$.

Based on the demand and control dimensions (low and high), the Demand-Control quadrants were categorized into 'high strain jobs' (high psychological demand and low control); 'active jobs' (high psychological demand and high control); 'passive jobs' (low psychological demand and low control) and 'low strain jobs' (low psychological demand and high control) ${ }^{(8-10)}$.

Reliability was verified by estimating internal consistency in the global scale and its respective dimensions using Cronbach's alpha coefficient: the psychological demand reached 0.649 and the control dimension reached 0.523 . In the evaluation of sub-items in the control dimension, Cronbach's alpha presented greater consistency for "decision-making authority" (0.627). 
Other variables were considered according to two groups: reported socio-demographic variables (ethnicity, age, education, income, marital status, and number of children) and occupational variables (position, weekly workload, time in the current position, sector, social support). The scores of social support were defined

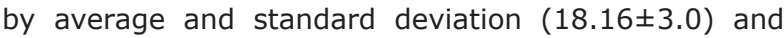
classified either as low social support (score $\leq 18$ ) or high social support (score $\geq 19$ ).

The results were descriptively analyzed through central tendency measures (average or median) and variability (standard deviation or interquartile amplitude) as well as absolute and relative distribution ( $n-\%)$. Symmetry of continuous distributions was evaluated by the Kolmogorov-Smirnov test. The Chi-square test was used to compare proportions between categories of the same variable (univariate analysis) taking into account the theoretical distribution of homogeneity between the compared categories. In the contingency tables in which at least $25 \%$ of the cell values presented expected frequency below 5, Fisher's exact test was used, while in situations in which at least one variable had polytomous characteristics, the Monte Carlo simulation was used.

To identify related factors relevant to the demandcontrol quadrants, the Multinomial Logistic Regression model was used; Odds Ratio was used to evaluate and directly estimate the probability of an event occurring

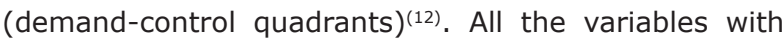
a minimum level of significance below 0.250 were considered in the non-adjusted logistic regression. In the selection of variables to be excluded from the initial model, the likelihood ratio test ( -2 log likelihood), obtained through the Chi-square test, for comparisons of the explicative variables and the dependent variable (demand-control quadrants) was performed.

The low demand quadrant was considered to be a reference group (lower risk of becoming ill) for the logistic regression according to the model proposed by Karasek and Theörell( ${ }^{(9)}$. Data were statistically analyzed using the Statistical Package for Social Sciences ${ }^{\circledR}$ (SPSS) version 17.0, Chicago, IL, USA. For decision criteria, level of significance $(\alpha)$ was fixed at $5 \%$. When probability was situated between 0.05 and 0.10 , the level of significance was considered the limit.

The research project was approved by the Ethics Research Committee at the Pontifical Catholic University of Rio Grande do Sul (PUCRS) (Protocol No. OF.CEP997/09) and the City Health Department (CEP 399
Protocol No 001.044987.09.9) and each participant signed free and informed consent forms.

\section{Results}

This study's sample $(n=388)$ was initially evaluated in relation to socio-demographic and occupational aspects. The participants presented an average age of 48.3 years old $( \pm 7.2)$, with a minimum age of 29 years old and a maximum of 68 years; ages between 49 to 59 years old $(41.8 \%)$ were in the majority; $81.2 \%$ were women; 58\% had completed secondary school; and most were married or lived in stable unions (56.4\%). Monthly income was not reported by 29 (7.4\%) professionals of the 359 professionals who answered this variable, $50.6 \%(n=180)$ reported monthly per capita income up to $\mathrm{R} \$ 1,200.00^{*} ; 50 \%$ of the professionals had from two to four family members.

In relation to occupational characteristics, the sectors that had the largest number of workers were Intensive Care Units (ICUs) with 39.4\% ( $n=153)$, followed by Surgical Centers with $14.4 \%(n=56)$, hospitalization units with $23.5 \%(n=91)$, and emergency units with $22.7 \%(n=88)$. More than half of the professionals $(51.5 \% ; n=200)$ reported they worked on the night shift and most worked 12 hours per shift $(75.3 \% ; n=292)$.

In relation to their position, $14.9 \%(n=58)$ were nurses and $85.1 \%(n=330)$ were nursing technicians and auxiliaries. These professionals worked in these positions between one and 37 years, with an average of 15.9 years $( \pm 6.7) ; 54.6 \%$ of the participants worked for 16 years or more in their position; $82.9 \%(n=322)$ did not have an extra job. In relation to social support $53.9 \%(n=209)$ of the professionals were classified as having low social support.

In relation to the psychological demand, answers presented an average score of $14.6( \pm 2.4)$, which ranged from 7 to 19; the number of professionals classified as having low psychological demand was significantly $(p<0.001)$ higher.

An average score of $16.9( \pm 2.4)$ was obtained in the dimension 'control over work', with minimum and maximum scores of 8 and 22, respectively; the number of professionals with low control was significantly high $(p=0.006)$.

Table 1 presents the dimensions 'psychological demand' and 'control' (low and high) and the JSS demand-control quadrants.

* Exchange rate at the time was US $\$ 1.00=R \$ 1.80$ 
Table 1 - Frequency of psychological demand, control over job and the JSS demand-control quadrants. Porto Alegre, RS, Brazil, 2010

\begin{tabular}{lc}
\hline \multicolumn{1}{c}{ Job Stress Scale variables } & $\mathbf{n}(\%)$ \\
\hline Psychological Demand & $241(62.1)$ \\
Low Demand $(\downarrow D)$ & $147(37.9)$ \\
High Demand ( $\uparrow$ D) & \\
Control over job & $221(57.0)$ \\
Low Control $(\downarrow C)$ & $167(43.0)$ \\
High Control $(\uparrow C)$ & \\
Demand-Control Quadrants (JSS) & $103(26.5)$ \\
Low strain $(\downarrow D \uparrow C)$ & $138(35.6)$ \\
Passive job $(\downarrow D \downarrow C)$ & $64(16.5)$ \\
Active job $(\uparrow D \uparrow C)$ & $83(21.4)$ \\
High Strain $(\uparrow D \downarrow C)$ & \\
\hline
\end{tabular}

The socio-demographic profile of the nursing workers classified in the demand-control quadrants is presented in Table 2. The variables gender, age, marital status and per capita income were not statistically associated with the demand-control quadrants.

Table 3 presents the occupational profile of these workers and shows a statistically significant association with work sector, position and social support. No statistically significant differences were found for the variables 'time in the position', 'work shift', and 'extra job' ( $p>0.05)$.

Table 2 - Distribution of the socio-demographic variables according to the JSS demand-control quadrants. Porto Alegre, RS, Brazil, 2010

\begin{tabular}{|c|c|c|c|c|c|c|}
\hline \multirow{2}{*}{ Socio demographic variables } & \multirow{2}{*}{$\mathbf{n}$} & \multicolumn{4}{|c|}{ Demand-Control Quadrants n (\%) } & \multirow[b]{2}{*}{$\mathbf{p}$} \\
\hline & & $\begin{array}{c}\text { Low strain } \\
n=103\end{array}$ & $\begin{array}{c}\text { Passive job } \\
n=138\end{array}$ & $\begin{array}{c}\text { Active job } \\
n=64\end{array}$ & $\begin{array}{l}\text { High strain } \\
n=83\end{array}$ & \\
\hline \multicolumn{7}{|l|}{ Gender } \\
\hline Male & 73 & $24(32.9)$ & $26(35.6)$ & $9(12.3)$ & $14(19.2)$ & $0.474^{*}$ \\
\hline Female & 315 & $79(25.1)$ & $112(35.6)$ & $55(17.5)$ & $69(21.9)$ & \\
\hline \multicolumn{7}{|l|}{ Age Range } \\
\hline From 29 to 40 years old & 59 & $16(27.1)$ & $21(35.6)$ & $9(15.3)$ & $13(22.0)$ & $0.654^{*}$ \\
\hline From 41 to 48 years old & 153 & $32(24.8)$ & $39(30.2)$ & $26(20.2)$ & $32(24.8)$ & \\
\hline From 49 to 59 years old & 162 & $51(28.5)$ & $69(38.5)$ & $27(15.1)$ & $32(17.9)$ & \\
\hline 60 years old or older & 14 & $4(19.0)$ & $9(42.9)$ & $2(9.5)$ & $6(28.6)$ & \\
\hline \multicolumn{7}{|l|}{ Education } \\
\hline No bachelor's degree & 245 & $57(23.3)$ & $95(38.8)$ & $35(14.3)$ & $58(23.7)$ & $0.042^{*}$ \\
\hline Bachelor's degree & 143 & $46(32.2)$ & $43(30.1)$ & $29(20.3)$ & $25(17.5)$ & \\
\hline \multicolumn{7}{|l|}{ Marital status } \\
\hline Married/stable union & 219 & $62(28.3)$ & $78(35.6)$ & $37(16.9)$ & $42(19.2)$ & $0.617^{*}$ \\
\hline Single/separated/divorced/widowed & 169 & $41(24.3)$ & $60(35.5)$ & $27(16.0)$ & $41(24.3)$ & \\
\hline \multicolumn{7}{|l|}{ Per capita income } \\
\hline Up to $R \$ 1,200.00$ & 180 & $43(23.9)$ & $70(38.9)$ & $25(13.9)$ & $42(23.3)$ & $0.163^{*}$ \\
\hline$>\mathrm{R} \$ 1,200.00$ & 179 & $54(30.7)$ & $53(30.1)$ & $33(18.8)$ & $38(20.5)$ & \\
\hline
\end{tabular}

* Pearson's Chi-square.

Table 3 - Distribution of occupational variables according to the JSS demand-control quadrants. Porto Alegre, RS, Brazil, 2010

\begin{tabular}{|c|c|c|c|c|c|c|}
\hline \multirow[b]{2}{*}{ Occupational variables } & \multirow[b]{2}{*}{$\mathbf{n}$} & \multicolumn{4}{|c|}{ Demand-Control Quadrants n (\%) } & \multirow[b]{2}{*}{$\mathbf{p}$} \\
\hline & & $\begin{array}{c}\text { Low strain } \\
n=103\end{array}$ & $\begin{array}{c}\text { Passive job } \\
n=138\end{array}$ & $\begin{array}{c}\text { Active job } \\
n=64\end{array}$ & $\begin{array}{l}\text { High strain } \\
n=83\end{array}$ & \\
\hline \multicolumn{7}{|l|}{ Work sector } \\
\hline Surgical Center & 56 & $10(17.9)$ & $23(41.1)$ & $10(17.9)$ & $13(23.2)$ & $0.004^{*}$ \\
\hline Hospitalization & 91 & $26(28.6)$ & $25(27.5)$ & $12(13.2)$ & $28(30.8)$ & \\
\hline $\mathrm{ICU}$ & 153 & $48(31.4)$ & $65(42.5)$ & $21(13.7)$ & $19(12.4)$ & \\
\hline Emergency & 88 & $19(21.6)$ & $25(28.4)$ & $21(23.9)$ & $23(26.1)$ & \\
\hline \multicolumn{7}{|l|}{ Work shift } \\
\hline Day & 188 & $54(28.7)$ & $62(33.0)$ & $34(18.1)$ & $38(20.2)$ & $0.545^{*}$ \\
\hline Night & 200 & $49(24.5)$ & $76(38.0)$ & $30(15.0)$ & $45(22.5)$ & \\
\hline
\end{tabular}


Table 3 - (continuation)

\begin{tabular}{|c|c|c|c|c|c|c|}
\hline \multirow{2}{*}{ Occupational variables } & \multirow{2}{*}{$\mathbf{n}$} & \multicolumn{4}{|c|}{ Demand-Control Quadrants n (\%) } & \multirow[b]{2}{*}{$\mathbf{p}$} \\
\hline & & $\begin{array}{l}\text { Low strain } \\
\qquad n=103\end{array}$ & $\begin{array}{c}\text { Passive job } \\
n=138\end{array}$ & $\begin{array}{c}\text { Active job } \\
n=64\end{array}$ & $\begin{array}{l}\text { High strain } \\
\quad n=83\end{array}$ & \\
\hline \multicolumn{7}{|l|}{ Workload } \\
\hline 6 hours & 96 & $27(28.1)$ & $34(35.4)$ & $17(17.7)$ & $18(18.8)$ & $0.885^{*}$ \\
\hline 12 hours & 192 & $76(26.0)$ & $104(35.6)$ & $47(16.1)$ & $65(22.3)$ & \\
\hline \multicolumn{7}{|l|}{ Position } \\
\hline Nurse & 58 & $25(43.1)$ & $8(13.8)$ & $20(34.5)$ & $5(8.6)$ & $<0.001^{*}$ \\
\hline Technician/Auxiliary & 330 & $78(23.6)$ & $130(39.4)$ & $44(19.3)$ & $78(24.1)$ & \\
\hline \multicolumn{7}{|l|}{ Time in position } \\
\hline Up to 15 years old & 176 & $55(31.3)$ & $66(37.5)$ & $23(13.1)$ & $32(18.2)$ & $0.076^{*}$ \\
\hline$>15$ years & 212 & $48(22.6)$ & $72(34.0)$ & $41(64.1)$ & $51(61.4)$ & \\
\hline \multicolumn{7}{|l|}{ Another job } \\
\hline No & 66 & $80(24.8)$ & $116(36.0)$ & $56(17.4)$ & $70(21.7)$ & $0.361^{*}$ \\
\hline Yes & 322 & $23(34.8)$ & $22(33.3)$ & $8(12.1)$ & $13(19.7)$ & \\
\hline Social support & & & & 冫 & & \\
\hline Low & 209 & $44(21.5)$ & $67(32.1)$ & $36(17.2)$ & $61(29.2)$ & $<0.001^{*}$ \\
\hline High & 179 & $59(32.4)$ & $71(39.7)$ & $28(15.6)$ & $22(12.3)$ & \\
\hline
\end{tabular}

* Pearson's Chi-square test.

The application of adjusted and non-adjusted logistic regression is presented in Tables 4 and 5. Table 5 presents the variables that most reliably represent the association with demand-control quadrants. Holding the low demand quadrant as a reference, being a nursing auxiliary or technician, working in the position for more than 15 years, and having low social support were positively associated and indicated increased chances of an individual to be classified in the high strain quadrant. A nursing technician or auxiliary had a greater chance of belonging to the passive job quadrant while workers with more than 15 years in the position had a greater chance of belonging to the active job quadrant; workers from hospitalization units or ICUs had a lower risk of belonging to the active job quadrant.

Table 4 - Association of demand-control quadrants and co-variables generated in raw regression taking low strain as reference. Porto Alegre, RS, Brazil, 2010

\begin{tabular}{|c|c|c|c|c|}
\hline \multirow[b]{2}{*}{ Variables } & \multicolumn{4}{|c|}{ Demand-Control Quadrants - n(\%) } \\
\hline & Low Strain & $\begin{array}{l}\text { Passive job } \\
\text { OR (IC95\%) }\end{array}$ & $\begin{array}{l}\text { Active job } \\
\text { OR (IC95\%) }\end{array}$ & $\begin{array}{l}\text { High Strain } \\
\text { OR (IC95\%) }\end{array}$ \\
\hline \multicolumn{5}{|l|}{ Education } \\
\hline Bachelor's degree & 1.000 & $0.456(0.288-1.547)$ & $0.657(0.256-1.855)$ & $0.523(0.254-1.332)$ \\
\hline No bachelor's degree & 1.000 & $1.037(0.541-1.988)$ & $1.492(0.596-3.732)$ & $1.097(0.507-2.372)$ \\
\hline \multicolumn{5}{|l|}{ Sector* } \\
\hline Emergency & 1.000 & $0.567(0.113-1.032)$ & $2.021(0.954-8.514)$ & $0.623(0.154-2.011)$ \\
\hline Surgical Center & 1.000 & $2.007(0.751-5.364)$ & $0.923(0.309-2.758)$ & $1.285(0.433-3.810)$ \\
\hline Hospitalization & 1.000 & $0.981(0.424-2.272)$ & $0.383(0.147-1.002)$ & $1.304(0.540-3.145)$ \\
\hline ICU & 1.000 & $1.359(0.652-2.833)$ & $0.409^{\dagger}(0.176-0.953)$ & $0.539(0.227-1.279)$ \\
\hline \multicolumn{5}{|l|}{ Position* } \\
\hline Nurse & 1.000 & $0.855(0.541-2.054)$ & $2.045(0.964-5.623)$ & $0.356(0.104-0.867)$ \\
\hline Nursing technician/Auxiliary & 1.000 & 1.000 & $0.923(0.458-1.954)$ & $2.895^{\dagger}(1.235-7.441)$ \\
\hline \multicolumn{5}{|l|}{ Time in position* } \\
\hline$\leq 15$ years & 1.000 & $0.488(0.204-1.741)$ & $0.421(0.201-0.887)$ & $0.358(0.162-0.966)$ \\
\hline$>15$ years & 1.000 & $1.954(0.899-3.712)$ & $2.309^{\dagger}(1.456-3.224)$ & $2.056^{\dagger}(1.004-6.889)$ \\
\hline \multicolumn{5}{|l|}{ Social Support* } \\
\hline High & 1.000 & $0.752(0.369-1.688)$ & $0.665(0.306-1.714)$ & $0.522(0.258-0.889)$ \\
\hline Low & 1.000 & $1.404(0.815-2.417)$ & $1.671(0.865-3.228)$ & $5.088^{*}(2.572-10.067)$ \\
\hline
\end{tabular}

Estimates obtained by multivariate logistic regression analysis.

${ }^{*} \mathrm{p}<0.01 ;{ }^{\dagger} \mathrm{p}<0.05$ 
The Pseudo- $\mathrm{R}^{2}$ obtained in the application of the raw logistic regression was 0.249 with "-2 log Likelihood" of 605.149 . The new regression in the adjusted model presented an estimate of Pseudo- $R^{2}$ of 0.328 , that is, the final model explained about $32.8 \%$ of variations recorded by the variable 'demand-control quadrants'.
Adequacy proved to be relevant with "-2 log Likelihood" of 380.009, which indicates a more efficient model. However, with this Pseudo- $R^{2}$, the model does not completely discriminate, leaving $67.2 \%$ of variations explained by the model, which may indicate that there are other factors not addressed in this study.

Table 5 - Association of the demand-control quadrants and co-variables generated in the adjusted regression, taking low strain as the reference. Porto Alegre, RS, Brazil, 2010

\begin{tabular}{|c|c|c|c|c|}
\hline \multirow{2}{*}{ Variations } & \multicolumn{4}{|c|}{ Demand-Control Quadrants } \\
\hline & Low Strain & $\begin{array}{l}\text { Passive job } \\
\text { OR (IC95\%) }\end{array}$ & $\begin{array}{l}\text { Active job } \\
\text { OR (IC95\%) }\end{array}$ & $\begin{array}{l}\text { High Strain } \\
\text { OR (IC95\%) }\end{array}$ \\
\hline \multicolumn{5}{|l|}{ Sector* } \\
\hline Emergency & 1.000 & $0.623(0.288-1.154)$ & $2.355(1.551-6.225)$ & $0.788(0.301-2.223)$ \\
\hline Surgical Center & 1.000 & $1.980(0.747-5.243)$ & $0.898(0.301-2.677)$ & $1.235(0.421-3.601)$ \\
\hline Hospitalization & 1.000 & $0.920(0.400-2.113)$ & $0.375^{*}(0.144-0.979)$ & $1.177(0.495-2.797)$ \\
\hline $\mathrm{ICU}$ & 1.000 & $1.249(0.607-2.568)$ & $0.409^{\dagger}(0.178-0.940)$ & $0.468(0.201-1.093)$ \\
\hline \multicolumn{5}{|l|}{ Position* } \\
\hline Nurse & 1.000 & $0.489(0.161-0.863)$ & $0.698(0.452-2.711)$ & $0.418(0.122-0.799)$ \\
\hline Nursing auxiliary/technician & 1.000 & $3.718^{*}(1.987-7.611)$ & $1.794(0.874-3.124)$ & $3.845^{\dagger}(1.745-8.665)$ \\
\hline \multicolumn{5}{|l|}{ Time in position* } \\
\hline$\leq 5$ years & 1.000 & $0.725(0.401-2.021)$ & $0.567(0.118-1.007)$ & $0.402(0.216-0.804)$ \\
\hline$>15$ years & 1.000 & $1.813(0.865-2.955)$ & $2.127^{\dagger}(1.216-6.118)$ & $2.254^{\dagger}(1.102-8.637)$ \\
\hline \multicolumn{5}{|l|}{ Social Support* } \\
\hline High & 1.000 & $0.825(0.488-2.156)$ & $0.504(0.278-1.205)$ & $0.417(0.189-0.725)$ \\
\hline Low & 1.000 & $1.358(0.794-2.322)$ & $1.681(0.877-3.222)$ & $4.799^{*}(2.456-9.377)$ \\
\hline
\end{tabular}

Estimates obtained by multivariate logistic regression analysis.

$* \mathrm{p}<0.01 ;{ }^{\mathrm{p}} \mathrm{p}<0.05$

Adjusted for education and per capita income

\section{Discussion}

Workplace stress in nursing workers from an emergency hospital was evaluated in this study. The results revealed that nursing technicians or auxiliaries, individuals working for more than 15 years in the position, and those with low social support, have a greater chance of presenting high strain. Being a nursing technician or auxiliary also results in a greater chance of belonging to the passive job quadrant. Both quadrants represent a greater risk of becoming ill.

In the analysis of the dimensions 'psychological demand' and 'control over work', the studied group presented a greater frequency in the passive job quadrant $(35.6 \%)$. This result suggests observation and follow-up are required because, according to the model, it may indicate loss of skills and interest related to work on the part of workers ${ }^{(8-9)}$. Combining with these workers those classified as belonging to the high strain quadrant $(21.4 \%)$, we verify that a large number of workers $(57 \%)$ belong to quadrants that represent a risk to health.
Four studies conducted in Brazil used the DemandControl Model in investigations addressing nursing workers in hospital facilities. The percentages found in the study conducted in a hospital in Bahia(1), Brazil were lower for passive job and higher for high strain (28.4\% and $27.8 \%$ respectively), but similar if compared to the sum of the two quadrants (56.2\%). Another study addressing nursing workers from critical units of a hospital in Rio Grande do Sul(13), Brazil also found a lower percentage for passive job and higher for high strain ( $19.7 \%$ and $44.1 \%$ respectively); thus, $63.8 \%$ of the workers was classified in these quadrants.

A study conducted with nursing workers from a public university hospital in the Midwest region of Rio Grande do Sul(6) found a lower result for passive job and similar to this study for high strain $(29.9 \%$ and $21.2 \%$ respectively), that is, $51.1 \%$ of the workers belonged to quadrants that presented risk to health. The other study addressing nursing workers from a city hospital in Rio de Janeiro(2), RJ, Brazil reports data opposite to these: 
lower frequency of workers in the passive job and high strain ( $16.6 \%$ and $17.9 \%$ respectively), or only $34.5 \%$ of the workers belonged to quadrants that represent risk to health.

Two international studies addressing nursing workers also report important results. One of them, conducted in a Korean hospital, reported a lower percentage for passive job and higher percentage for high strain ( $26.1 \%$ and $29.2 \%$ respectively), totaling $55.3 \%$ of workers in these quadrants ${ }^{(14)}$. The other study reports a greater concentration of nurses in the passive job and high strain quadrants $(32.1 \%$ and $25.8 \%$ respectively) ${ }^{(15)}$

Another study reports that the low psychological demand identified among nursing workers was similar to that found among nursing technicians and auxiliaries(6). Such results are surprising, since the general context of the nursing job imposes an intense job pace ${ }^{(16)}$, often generated by the excessive demand of hospitalized patients ${ }^{(17)}$. The low psychological demand of the studied workers is linked to the fact that there are psychological conditions such as the time to perform tasks, fewer urgent situations, or little need to reorganize their jobs. Such a fact may be related to aspects such as continuity of job (nurses are present for 24 hours) and teamwork (46.1\% of the professionals reported high social support).

There was a concentration of workers in the low control quadrant, probably because only $14.9 \%$ of the workers were nurses. A study evaluating the dimension 'control according to position', revealed that $75.3 \%$ of nurses had high control over job and $62.3 \%$ of the nursing technicians and auxiliaries had low control(6). Low control over job is of concern because it characterizes a job process highly repetitive with limited autonomy and few opportunities to learn new things. This aspect may demotivate workers and generate low self-esteem, which according to the authors of the Demand-Control Model, are developments that are very harmful to workers' health.

Socio-demographic characteristics were not statistically associated with the demand-control quadrants, with the exception of the variable 'education'. While professionals who were college graduates significantly associated with the active job and low strain quadrants, those who did not have a bachelor's degree were significantly associated with passive jobs and high strain. Being a nurse was also associated with the low risk quadrants, which may be related to the educational level previously mentioned, since this position requires higher education.
Other studies found a positive association between educational level and the quadrants, while nursing professionals who fit into the passive job and high strain quadrants were mainly individuals with no bachelor's degrees $^{(1,18)}$

The occupational characteristics statistically associated with the demand-control quadrants were sector (not confirmed in the logistic regression), position, time in position, and social support. In relation to sector, the high strain quadrant most frequently concentrated professionals working in the hospitalization and emergency sectors. The hospitalization unit being classified as high strain was a surprise, because ICUs and the emergency sectors are usually the ones associated with occupational stress ${ }^{(19-20)}$. Another study reported representativeness of data in ICU in the high strain (53.0\%) and passive job (51.8\%) quadrants ${ }^{(1)}$.

Characteristics related to work that place hospitalization units in the same quadrant as ICUs need to be investigated in this specific hospital. An element to take into account is that the number of patients cared for by a health provider in a hospitalization unit is usually higher than is the case in ICUs. The latter has its own regulations concerning the maximum number of patients to be cared for by nurses and nursing technicians and auxiliaries.

The findings related to position corroborate the organization of nursing work, in which actions are distributed according to a hierarchy and complexity of care. Nurses are responsible for planning, controlling and evaluating the work process and manual activities of greater complexity while nursing technicians or auxiliaries are responsible for manual activities of lower complexity and those prescribed by nurses ${ }^{(21)}$. This fact may explain the concentration of nurses in quadrants that do not present harm to health (low strain and active job) and the concentration of nursing auxiliaries and technicians in quadrants that represent risk to health (high strain and passive job). These data were also found in other studies ${ }^{(1,6)}$.

Working in the same position more than 15 years was associated with the quadrant high strain, with a 2.25 times greater chance when compared to the low strain quadrant. This fact is extremely relevant because there are a high number of professionals working in public facilities who remain in their positions unti they retire. Even though this study does not provide evidence for an association between age and demandcontrol quadrants, other studies associate old age with illness. Another study found association between 
professionals working for 12 years or more in the same position and the passive job quadrant(22). Professionals working for more than 15 years in the same position also presented greater chances of being classified in the active job quadrant, while the sectors that presented the lower chances of being classified as active job were hospitalization and ICUs.

In this study, low social support presented statistically significant association with the quadrant high strain (with 4.80 times more chance than for the low strain quadrant). It may indicate that people with low levels of social interaction with colleagues and bosses tend to develop health disorders as reported in the Demand-Control Model(10). These results were also found in another study, in which professionals in the high strain quadrant reported low social support(1).

Relationships established in the workplace characterize an extremely vulnerable aspect in the context of nursing work. Relationships of subordination (nursing technicians and auxiliaries in relation to nurses) often include difficult and conflictive interactions since knowledge of the work process is easily developed in practice but responsibilities are rigidly defined in the formalization of positions.

\section{Conclusions}

This study found associations of stress, based on the JSS, with occupational aspects in nursing professionals working in an emergency hospital service. Information concerning occupational stress related to position, time in position, and social support can be used to seek proactive actions to minimize occupational stress and the impact it has on the health of workers. This study indicates factors that represent a risk to the health of workers and can serve as a theoretical basis in the search for preventive interventions.

Even though the model does not explain the variations and aspects related to the object of study, this study does present contributions relevant to nursing, since occupational characteristics were more relevant in the association with occupational stress, showing that aspects related to the workplace should be monitored by health institutions and competent bodies aiming to invest in the quality of life of nursing workers.

Further research of a follow-up design is needed to validate the relationship between the dimensions 'psychological demand' and 'control over work' and occupational aspects and the health of workers. Because this was a cross-sectional study, evidence concerning the effective risk of health disorders of the studied workers were limited.

\section{Acknowledgements}

We thank the managers and nursing professionals at the studied hospital for their support that enabled this study, Tânia S. Bosi de Souza Magnago for her attention and clarification and also Cátia Daiane Souza Silveira for her assistance in the data collection process.

\section{References}

1. Araújo TM, Aquino E, Menezes G, Santos CO, Aguiar L. Aspectos psicossociais do trabalho e distúrbios psíquicos entre trabalhadoras de enfermagem. Rev Saúde Pública. 2003;37(4):424-33.

2. Silva JLL. Estresse e transtornos mentais comuns em trabalhadores de enfermagem [dissertação]. Rio de Janeiro (RJ): Universidade Federal do Estado do Rio de Janeiro; 2007. 174 p.

3. Alves MGM, Chor D, Faerstein E, Werneck GL, Lopes CS. Estresse no trabalho e hipertensão arterial em mulheres no Estudo Pró-Saúde. Rev Saúde Pública. 2009;43(5):893-6.

4. Schmidt DRC, Dantas RAS, Marziale MHP, Laus AM. Estresse ocupacional entre profissionais de enfermagem do bloco cirúrgico. Texto Contexto Enferm. 2009;18(2):330-7.

5. Magnago TSBS, Lisboa MTL, Griep RH. Trabalho da enfermagem e distúrbio musculoesquelético: revisão das pesquisas sobre o tema. Esc Anna Nery. 2008;12(3):560-5.

6. Magnago TSBS, Lisboa MTL, Griep RH, Zeitoune RCG, Tavares JP. Working conditions of nurses: evaluation based on the demand-control model. Acta Paul Enferm. 2010;23(6):811-7.

7. Juarez-Garcia A. Factores psicosociales laborales relacionados con la tensión arterial y sintomas cardiovasculares en personal de enfermeria en México. Salud Pública México. 2007;49(2):109-17.

8. Karasek RA. Job demands, job decision latitude, and mental strain: implications for job redesign. Adm Sci Q. $1979 ; 24: 285-308$.

9. Karasek R, Theorell T. Healthy work: stress, productivity and the reconstruction of working life. New York: Basic Books; 1990.

10. Alves MGM, Chor D, Faerstein E, Lopes CS, Werneck GL. Versão resumida da "Job Stress Scale": adaptação para o português. Rev Saúde Pública. 2004;38(2):164-71. 
11. Lallukka T, Lahelma E, Rahkonen O, Roos E, Laaksonen

E, Martikainen $P$, et al. Associations of job strain and working overtime with adverse health behaviors and obesity: evidence from the Whitehall II Study, Helsinki Health Study, and the Japanese Civil Servants Study. Soc Sci Med. 2008;66(8):1681-98.

12. Hosmer DW, Lemeshow S. Applied logistic regression. 2nd ed. New York: John Wiley; 2000.

13. Amaral TR. Dimensões psicossociais do trabalho da enfermagem e os distúrbios psíquicos menores em unidades críticas [dissertação]. Florianópolis (SC): Universidade Federal de Santa Catarina - Programa de Pós-graduação em Enfermagem; 2006. 114 p.

14. Ha M, Park J. Shiftwork and metabolic risk factors of cardiovascular disease. J Occup Health. 2005;47(2):89-95.

15. Lee S, Colditz G, Berkman L, Kawachi I. A prospective study of job strain and coronary heart disease in US women. Int J Epidemiol. 2002;31(6):1147-53.

16. Gonzales RMB. Sofrimento na práxis da enfermagem: real ou deslocado em seu sentido? Florianópolis (SC): UFSC; 2000. 183 p.

17. O’Dwyer GO, Oliveira SP, Seta MH. Avaliação dos serviços hospitalares de emergência do programa QualiSUS. Ciênc Saúde Colet. 2009;14(5):1881-90.

18. Aboa-Éboulé C, Brisson C, Maunsell E, Mâsse B, Bourbonnais $R$, Vézina $M$, et al. Job strain and risk of acute recurrent coronary heart disease events. JAMA. 2007;298(14): 1652-60.

19. Cavalheiro AM, Moura DF Junior, Lopes AC. Stress in nurses working in intensive care units. Rev. Latino-Am. Enfermagem. 2008;16(1):29-35.

20. Batista KM, Bianchi ERF. Stress among emergency unit nurses. Rev. Latino-Am. Enfermagem. 2006;14(4):534-9.

21. Lei n. 7.498, de 25 de junho de 1986 (BR). Conselho Federal de Enfermagem. Dispõe sobre a regulamentação do exercício da Enfermagem e dá outras providências. Diário Oficial da União. Seção I-fls. 9.273 a 9.275 [periódico na internet]. [acesso 1 maio 2011]. 26 de junho de 1986. Disponível em: http://www.portalcofen. gov.br/sitenovo/node/4161.

22. Alves MGM. Pressão no trabalho: estresse no trabalho e hipertensão arterial em mulheres no Estudo Pró-Saúde [tese de doutorado]. Rio de Janeiro (RJ): Fundação Oswaldo Cruz - Escola Nacional de Saúde Pública; 2004. 259 p. 